\title{
ANALISIS INTEGRASI PASAR KOPI DI KABUPATEN GARUT
}

\section{Coffee Market Integration Analysis In Garut District}

\author{
T. Mulyana1 \\ 1 Program Studi Agribisnis Fakultas Pertanian Universitas Garut, \\ Jl. Raya Samarang No. 52A Tarogong Kaler Garut 44151, Indonesa \\ Email : tatang.mulyana@uniga.ac.id
}

\begin{abstract}
ABSTRAK
Dalam perdagangan komoditas pertanian yang efisien maka harga yang terjadi di kota kabupaten maupun antar kota kecamatan bahkan sampai desa akan terintegrasi, dan pergerakan harga akan bersifat simetri. Pada kenyataannya dalam dunia agribisnis ada kekuatan pasar oligopoli (pedagang besar propinsi) yang mengendalikan harga. Kekuatan pasar dapat pula ditentukan oleh kekuatan monopsoni ataupun oligopsoni (para pedagang besar kabupaten) karena memiliki pangsa pasar yang sangat besar. Penelitian ini bertujuan untuk mengetahui apakah perubahan harga di tingkat eceran di kota kabupaten terintegrasi dengan perubahan harga di tingkat petani di desa. Metoda penelitian yang digunakan menggunakan pendekatan kuantitatif yaitu analisis integrasi pasar dan transmisi harga. Elastisitas transmisi menghitung apakah laju perubahan harga di tingkat eceran akan ditransmisikan ke tingkat petani. Hasil penelitian menunjukkan bahwa berdasarkan elastisitas transmisi, laju perubahan harga di tingkat petani lebih kecil daripada laju perubahan harga di tingkat pengecer, baik untuk pasar local kecamatan maupun pasar pusat kabupaten. Berdasarkan nilai IMC (index of market conection), nilainya lebih besar dari satu artinya pasar di tingkat petani pada kecamatan contoh kurang terintegrasi dengan pasar lokal kecamatan dan pasar pusat di kabupaten.
\end{abstract}

Kata kunci : Integrasi harga, transmisi harga, kopi

ABSTRACT

In an efficient trade of agricultural commodities, prices that occur in district cities and between sub-districts and even villages will be integrated and price movements will be 
symmetrical. In fact, in the agribusiness world there is an oligopoly market power provincial wholesalers) that controls prices. Market power can also be determined by the power of monopsony or oligopsony (district wholesalers) because they have a very large market share. This study aims to determine whether price changes at the retail level in the district city are integrated with changes in prices at the farmer level in the village. The research method used is a quantitative approach, namely integration analysis and price transmission. The transmission elasticity calculates whether the rate of change in prices at the retail level will be transmitted to the farm level. The results showed that based on the elasticity of transmission, the rate of change in prices at the farmer level was smaller than the rate of change in prices at the retail level, both for the local market and the district central market. Based on the IMC (index of market connection) value, it means that the market at the farmer level in the sample sub-districts is less integrated with the local market and the central market in the district.

Keywords: Integration Analysis, price transmission, coffee.

\section{PENDAHULUAN}

Kabupaten Garut memiliki luas wilayah sekitar 307.407 hektar yang terdiri dari 42 kecamatan, 421 desa dan 21 kelurahan dengan jumlah penduduk mencapai 2.407.086 jiwa. Kepadatan penduduk sekitar 785 jiwa $/ \mathrm{km}^{2}$ dan laju pertumbuhan penduduk rata-rata 1.53 persen per tahun. Mata pencaharian masyarakat kabupaten Garut berasal dari sektor pertanian 39,23 persen, perdagangan 22,23 persen, jasa 14,44 persen, dan industri 9,46 persen (BPS, 2019). Sampai dengan saat ini sektor pertanian artinya masih memberikan sumbangan yang besar bagi perekonomian baik PAD dan penyediaan lapangan pekerjaan bagi masyarakat. Salah satu komoditas pertanian yang menjadi andalan kabupaten Garut adalah komoditas Kopi. Berikut ini adalah data luas areal panen (Ha) dan jumlah produksi Kopi di Propinsi Jawa Barat..

Kabupaten Garut merupakan daerah yang memiliki luas areal panen dan jumlah produksi Kopi terbesar kedua setelah kabupaten Bandungdi Jawa Barat. Dari table. 1 dapat dilihat luas areal dan produksinya. Pada tahun 2019 produksi kopi mencapai 2233 ton dengan rata-rata produksi sebesar $988 \mathrm{~kg} / \mathrm{Ha}$. Petani produsen sering tidak menikmati kenaikan harga yang terjadi di pasar kota kabupaten. Sebaliknya jika terjadi penurunan harga di kota kabupaten maka terkena dampak penurunan harga. Dari fenomena yang ada tersebut dirumuskan masalah dalam penelitian ini yaitu sejauhmana integrasi pasar kopi atau perubahan harga yang terjadi di lembaga pemasaran kopi yang ada di kota kabupaten mempengaruhi pembentukan harga di tingka petani produsen. Penelitian ini bertujuan untuk mengetahui apakah perubahan harga yang terjadi di lembaga pemasaran di tingkat pasar kota kabupaten akan mempengaruhi pembentukan 
harga di tingkat pasar kecamatan dan tingkat harga di petani produsen.

Tabel 1. Luas Areal dan Produksi Kopi Arabika Jawa Barat Tahun 2019

\begin{tabular}{llrrrrrr}
\hline & & \multicolumn{3}{c}{ Luas Tanam (Ha) } & \multicolumn{2}{c}{ Produksi } \\
\cline { 3 - 7 } No & Kabupaten/Kota & TBM & TM & TR/TTM & Total & Jumlah (Ton) & $\begin{array}{c}\text { Rata-rata } \\
\text { (Kg/Ha) }\end{array}$ \\
\hline 1 & Bandung & 4.272 & 8.157 & 262 & 12.691 & 6.700 & 821 \\
2 & Garut & 1.465 & 2.241 & 508 & 4.214 & 2.233 & 998 \\
3 & Bandung Barat & 1.222 & 1.331 & 28 & 2.581 & 825 & 620 \\
4 & Sumedang & 1.377 & 1.017 & 392 & 2.786 & 643 & 633 \\
5 & Cianjur & 1.075 & 642 & 132 & 1.832 & 225 & 350 \\
6 & Sukabumi & 329 & 773 & 154 & 1.255 & 186 & 241 \\
\hline & Jumlah & $\mathbf{9 . 7 4 0}$ & $\mathbf{1 4 . 1 6 1}$ & $\mathbf{1 . 4 7 6}$ & $\mathbf{2 3 . 3 5 9}$ & $\mathbf{1 0 . 8 1 2}$ & $\mathbf{3 . 6 6 3}$ \\
\hline
\end{tabular}

Sumber : Dinas Perkebunan Jawa Barat, (2019).

\section{METODOLOGI}

\section{Lokasi dan Waktu Penelitian}

Lokasi penelitian di sentra kopi Arabika di Kecamatan Pangatikan dan Kecamatan Sukawening Kabupaten Garut. Selain itu pengambilan data juga dilakukan di pasar kota kabupaten. Waktu penelitian berlangsung selam enam bulan dimulai pada Juni sampai dengan Desember 2020.

\section{Metode Analisis}

Metode penelitian yang digunakan adalah metode kuantitatif. Metode analisis data yaitu elastisitas transmisi dan integrasi harga pasar (IMC). Atas dasar asumsi bahwa harga di tingkat petani (Pf) dipengaruhi oleh harga di tingkat pengecer (Pr), maka dapat dirumuskan model regresi sederhana. Selanjutnya responden dipilih masing-masing 5 persen petani di sentra kopi arabika di Desa Talaga Bodas, pengecer di Kecamatan Pangatikan dan di kota kabupaten dengan teknik purposive sampling.

\section{HASIL DAN PEMBAHASAN}

\section{Saluran Pemasaran Kopi}

Saluran pemasaran kopi di lokasi penelitian terdiri dari dua saluran. Saluran pertama yaitu Petani - pengepul/bandar - pengolah/pedagang - konsumen akhir. Saluran ke dua yaitu dari Petani - Pengepul/Bandar - Usaha UMKM- Konsumen. Saluran ketiga yaitu dari petani - pengolah UMKM - konsumen akhir. Petani menjual biji kopi yang sudah dijemur dan dibuang kulitnya (green bean) seharga rata-rata Rp 15.000/kg. Pengepul/Bandar menjual green bean tersebut rata-rata Rp 
$17.000 / \mathrm{kg}$ dan Pengolah/pedagang besar di pasar kabupaten menjualnya dengan rata-rata harga $\mathrm{Rp} 21.000 / \mathrm{kg}$.

\section{Transmisi Harga}

Transmisi harga merupakan indikator efisiensi yang dapat menunjukkan laju perubahan harga di tingkat pasar tertentu lebih kecil, sama atau lebih besar dari laju perubahan harga di tingkat pasar lainnya. Tingkat pasar yang diperbandingkan laju perubahan harganya dalam penelitian ini adalah antara tingkat pasar petani dan pasar eceran baik pasar lokal ataupun pasar pusat di kota kecamatan. Hubungan harga di ke dua pasar tersebut diduga menggunakan model regresi. Data yang digunakan untuk melakukan pendugaan menggunakan data hasil survei langsung ke lokasi. Hasil pendugaan model tercantum dalam persamaan berikut :

Kecamatan Pangatikan

Petani Talaga Bodas dan Pasar Pangatikan $\quad$ :Pf $=11392,86+0,9$ PrC

Petani Talaga Bodas dan Pasar Kabupaten $\quad$ :Pf $=-12564,3+5,5$ PrK

Selanjutnya untuk transmisi harga ditunjukkan melalui nilai elastisitas transmisi harga yang dihitung dengan menggunakan rumus. Nilai elastisitas transmisi dapat dilihat pada Tabel 2 berikut. Dapat dilihat elastisitas transmisi di pasar kecamatan contoh ada lebih kecil dari satu untuk pasar petani produsen dan pasar eceran kecamatan serta untuk pasar desa dan pasar kabupaten. Artinya laju perubahan harga di tingkat pasar eceran kecamatan tidak ditransmisikan ke pasar di tingkat petani. Sedangkan untuk pasar pusat di Kabupaten, laju perubahan harga di tingkat petani lebih kecil dari laju perubahan harga di tingkat pasar pusat kabupaten. Maka dapat disimpulkan masih terdapat kekuatan monopsoni atau oligopsoni dalam pemasaran kopi di Kabupaten Garut.

Tabel 2. Nilai Elastisitas Transmisi Harga Kopi di Kabupaten Garut.

\section{Pangatikan}

Desa Talaga Bodas Pasar Pangatikan $\quad 0,01$

Desa Talaga Bodas-Pasar Kabupaten $\quad 0,05$

\section{Integrasi Pasar}

Analisis integrasi pasar sama seperti transmisi harga, didasarkan pada hubungan harga di tingkat petani dan tingkat eceran pada pasar local kecamatan maupun pasar pusat kabupaten. Berikut adalah tingkat integrasi pasar kopi di 
tingkat pasar desa dengan pasar Kopi di tingkat kecamatan. Selain itu juga katerkaitan harga di tingkat pasar desa dengan pasar di tingkat kabupaten. Analisis integrasi pasar menggunakan model yang dikembangkan oleh Ravallion (1986) dan Timmer (1987). Model ini didasarkan pada hubungan bedakala atau lag harga di suatu tingkat atau pasar tertentu dengan harga di pasar atau tingkat lainnya, misalnya harga di tingkat eceran dengan harga di tingkat petani. Model integrasi pasar dapat dinyatakan dengan persamaan:

$$
\mathrm{IMC}=\frac{1+\mathrm{b}_{1}}{\mathrm{~b}_{3}-\mathrm{b}_{1}}
$$

Jika IMC $<1$ atau mendekati nol maka semakin tinggi tingkat integrasi pasar. Sebaliknya jika IMC >1 artinya pasar dikatakan kurang terintegrasi.

Tabel 3. Nilai IMC Pasar Kopi di Kabupaten Garut

\begin{tabular}{ll}
\hline Kecamatan Pangatikan & IMC \\
Desa Talaga Bodas Pasar Pangatikan & 1,05 \\
Desa Talaga Bodas-Pasar Kabupaten & 1.10 \\
\hline
\end{tabular}

Berdasarkan dugaan persamaan model integrasi pasar dilakukan perhitungan IMC (index of market conection) dengan menggunakan rumus IMC. Nilai-nilai IMC untuk masing-masing pasar Kopi ditampilkan pada Tabel 3. Dari tabel 3. Dapat dilihat nilai IMC pasar Kopi di tingkat petani dan tingkat eceran pasar kecamatan dan pasar kabupaten di kecamatan contoh lebih besar dari satu. Ini menunjukkan bahwa pasar Kopi di kabupaten Garut kurang terintegrasi. Hal ini dapat terjadi pada pasar bersaing tidak sempurna, yaitu pasar yang di dalamnya terdapat kekuatan monopsoni atau oligopsoni. Demikian pula pasar Kopi di kabupaten Garut dipengaruhi juga oleh pasar Kopi dari daerah lain, artinya harga Kopi di kabupaten Garut tidak hanya dipengaruhi oleh permintaan dan penawaran Kopi di pasar lokal saja, tetapi juga dipengaruhi oleh permintaan dan penawaran pasar Kopi dari daerah lain.

\section{KESIMPULAN}

Berdasarkan analisis transmisi harga dan integrasi harga maka disimpulkan:

1. Laju perubahan harga di tingkat petani lebih kecil dibandingkan laju perubahan harga di tingkat eceran. Pemasaran Kopi belum efisien karena adanya kekuatan monopsoni atau oligopsoni yang turut mengendalikan harga.

2. Pasar Kopi di kabupaten Garut kurang terintegrasi antara pasar petani produsen, pasar kecamatan dan pasar pusat di kabupaten. Artinya pasar 
Kopi tidak bersaing sempurna, dan terdapat pengaruh dari pasar Kopi dari luar kabupaten.

\section{KESIMPULAN DAN REKOMENDASI KEBIJAKAN}

Berdasarkan analisis transmisi harga dan integrasi harga maka disimpulkan:

1. Laju perubahan harga di tingkat petani lebih kecil dibandingkan laju perubahan harga di tingkat eceran. Pemasaran Kopi belum efisien karena adanya kekuatan monopsoni atau oligopsoni yang turut mengendalikan harga.

2. Pasar Kopi di kabupaten Garut kurang terintegrasi antara pasar petani produsen, pasar kecamatan dan pasar pusat di kabupaten. Artinya pasar Kopi tidak bersaing sempurna, dan terdapat pengaruh dari pasar Kopi dari luar kabupaten.

\section{DAFTAR PUSTAKA}

BPS. 2019. Garut Dalam Angka. Badan Pusat Statistik Kab. Garut.

Ravallion, Martin. 1986. Testing Market Integration. American Journal of Agricultural Economics. Volume 68:L 102-109. 